Article

\title{
Study on Transglucosylation Properties of Amylosucrase from Xanthomonas campestris pv. Campestris and Its Application in the Production of $\alpha$-Arbutin
}

\author{
Chengyu Yang ${ }^{1,2}$, Weiming Fan ${ }^{2,3}$, Ruijie Zhang ${ }^{1,2,4}$, Jiping Shi ${ }^{1,2,4, *}$, \\ Zorica Knežević-Jugović ${ }^{5}$ and Baoguo Zhang ${ }^{1,2, *}$ \\ 1 Lab of Biorefinery, Shanghai Advanced Research Institute, Chinese Academy of Sciences, No. 99 Haike \\ Road, Pudong, Shanghai 201210, China; yangchengyu@sari.ac.cn (C.Y.); zhangrj@sari.ac.cn (R.Z.) \\ 2 University of Chinese Academy of Sciences, Beijing 100049, China; sxzyfwm@163.com \\ 3 Zhejiang Zhenyuan Pharmaceutical Co., Ltd. No. 61 North Yuedong Road, Shaoxing 312000, China \\ 4 School of Life Science and Technology, Shanghai Tech University, No. 393 Huaxia Middle Road, Pudong, \\ Shanghai 201210, China \\ 5 Department of Biochemical Engineering and Biotechnology, Faculty of Technology and Metallurgy, \\ University of Belgrade, Karnegijeva 4, Belgrade 11000, Serbia; zknez@tmf.bg.ac.rs \\ * Correspondence: shijp@sari.ac.cn (J.S.); zhangbg@sari.ac.cn (B.Z.); \\ Tel.: +86-021-2035166 (J.S.); +86-021-2035166 (B.Z.)
}

Received: 5 December 2018; Accepted: 18 December 2018; Published: 21 December 2018

\begin{abstract}
Arbutin (4-hydroquinone- $\alpha$-D-glucopyranoside), an effective skin-lightening agent due to its considerable inhibitory effect on human tyrosinase activity, is widely used in the pharmaceutical and cosmetic industries. Recently, $\alpha$-arbutin was prepared through transglucosylation of hydroquinone using microbial glycosyltransferases as catalysts. However, the low yield and prolonged reaction time of the biotransformation process of $\alpha$-arbutin production limited its industrial application. In this work, an amylosucrase (ASase) from Xanthomonas campestris pv. campestris str. ATCC 33913 (XCAS) was expressed efficiently in Escherichia coli JM109. The catalytic property of the purified XcAS for the synthesis of $\alpha$-arbutin was tested. The recombinant strain was applied for highly efficient synthesis of $\alpha$-arbutin using sucrose and hydroquinone as glucosyl donor and acceptor, respectively. By optimizing the biotransformation conditions and applying a fed-batch strategy, the final production yield and conversion rate of $\alpha$-arbutin reached $60.9 \mathrm{~g} / \mathrm{L}$ and $95.5 \%$, respectively, which is the highest reported yield by engineered strains. Compared to the highest reported value $(<1.4 \mathrm{~g} / \mathrm{L} / \mathrm{h})$, our productivity $(7.6 \mathrm{~g} / \mathrm{L} / \mathrm{h})$ was improved more than five-fold. This work represents an efficient and rapid method for $\alpha$-arbutin production with potential industrial applications.
\end{abstract}

Keywords: Amylosucrase; Xanthomonas campestris pv. Campestris; $\alpha$-arbutin; enzymatic properties; whole-cell biocatalyst; fed-batch strategy

\section{Introduction}

$\alpha$-Arbutin, a glycosylated hydroquinone, is a prominent natural compound used as a skin-whitening agent due to its antimelanogenesis effect without any cytotoxicity [1]. It has been reported that the inhibitory function of $\alpha$-arbutin against tyrosinase is 10 times greater than that of its isomer, $\beta$-arbutin [2]. Specifically, $\alpha$-arbutin only inhibits mammalian tyrosinase, while $\beta$-arbutin reduces tyrosinase activity by both melanoma and somatic cells [3]. Moreover, a study on cultured human melanoma cells and three-dimensional skin models indicates that $\alpha$-arbutin does not inhibit cell viability and exhibits outstanding performance in reducing melanin synthesis [2]. $\alpha$-Arbutin also 
shows antioxidative, antimicrobial, and anti-inflammatory functions. Therefore, the use of $\alpha$-arbutin as a safe and effective skin-whitening agent has received increasing attention in recent years.

A few strategies have been used to synthesize $\alpha$-arbutin from hydroquinone (HQ). Generally, two main strategies have been employed. The first involves applying microbial strains to transform HQ substrates into $\alpha$-arbutin. Native microbial strains such as Bacillus subtilis [4] and Xanthomonas campestris [5], as well as mutant strains of Xanthomonas maltophilia BT-112 [6-8], have been used to produce high concentrations of $\alpha$-arbutin. However, the relatively low productivity $(1.4 \mathrm{~g} / \mathrm{L} / \mathrm{h})$ of $\alpha$-arbutin synthesis and the use of immobilized substrate limited the large-scale application of the process. The second strategy involves HQ glycosylation via many different microbial glycosyltransferases. To date, at least seven different enzymes have been reported in $\alpha$-arbutin biosynthesis, including $\alpha$-glucosidase (EC 3.2.1.20) from Saccharomyces cerevisiae and Xanthomonas campestris [9,10], amylosucrase (EC 2.4.1.4) from Deinococcus geothermalis and Cellulomonas carboniz [11,12], sucrose phosphorylase (EC 2.4.1.7) and dextransucrase (EC 2.4.1.5) from Leuconostoc mesenteroides [13,14], $\alpha$-amylase (EC 3.2.1.1) from Bacillus subtilis X-23 [4], cyclodextrin glycosyltransferase (EC 2.4.1.19) from Thermoanaerobacter sp. [15], and sucrose isomerase (EC 5.4.99.11) form Erwinia rhapontici [16]. However, the production yield and molar conversion rate are low, which hampers their widespread application and commercialization. Compare with other microbial enzymes, amylosucrase displays prominent transglucosylation activity in $\alpha$-arbutin biosynthesis with sucrose as a glucosyl donor and hydroquinone as an acceptor.

Amylosucrase (ASase), belonging to the glycoside hydrolase 13 family, is a versatile enzyme catalyzing multiple reactions [17]. With sucrose and extra glucosyl acceptors as substrates, ASase has glucosyltransferase activity and can transfer glucose molecules from sucrose to glucosyl acceptors with $\alpha-1,4$ glycoside linkages only $[18,19]$. This enzyme utilizes the energy derived from the cleavage of glucosidic bonds in sucrose to synthesize other glycosides without involving any primer or nucleotide-activated sugars [20]. Recently, the ASase gene has been cloned from Deinococcus geothermalis and Cellulomonas carboniz for in vitro biosynthesis of $\alpha$-arbutin by using sucrose as a glucosyl donor and hydroquinone as acceptor [11,12]. In these studies, the high conversion rate $(90 \%)$ and low reaction time $(2 \mathrm{~h})$ revealed that amylosucrase has remarkably higher transglucosylation capacity, showing good potential for commercial production of $\alpha$-arbutin. As compared to the other transglucosidases, amylosucrase demonstrates higher efficiency in the synthesis of $\alpha$-arbutin. However, to date, its maximum production yields are still low $(5.8 \mathrm{~g} / \mathrm{L}$ and $0.6 \mathrm{~g} / \mathrm{L}$ for ASase from Deinococcus geothermalis and Cellulomonas carboniz, respectively). Thus, it is necessary to establish a simple and cost-effective method to produce $\alpha$-arbutin.

In this study, we first employed an ASase from X. campestris pv. campestris (XcAS) as the catalyst to synthesize $\alpha$-arbutin, and the catalytic property of the purified XcAS was clarified. In addition, $\alpha$-arbutin was synthesized by a whole-cell recombinant $E$. coli JM109/pet28a-xcas biocatalyst system using sucrose as glucoside donor and $\mathrm{HQ}$ as acceptor. Furthermore, a fed-batch strategy was employed to increase the production yield of $\alpha$-arbutin. Thus, this work represents a highly efficient method for $\alpha$-arbutin production with potential industrial applications.

\section{Results}

\subsection{XcAS Heterologous Expression and Protein Purification}

The XcAS encoding gene, locus XCC3359 from the X. campestris pv. campestris str. ATCC 33913 genome, consists of 1914 base pairs encoding 637 amino acid proteins. The target gene was synthesized and inserted into the pET28a (+) vector with $6 \times$ histidine tagged at its carboxyl terminus, resulting in expression of the pET28a-xcas plasmid. Through regulated expression of the $x$ cas gene under the control of a T7 promoter and lac repressor, it was transformed into E. coli JM109 [DE3]. As shown in Supplementary Figure S1A, the initial expression result of XcAS was almost manifested as inclusion bodies (IBs). To improve the production of soluble amylosucrase, the process conditions were optimized. As shown in Supplementary Figure S2, the results suggest that $0.1 \mathrm{mmol} / \mathrm{L}$ 
isopropyl $\beta$-D-1-thiogalactopyranoside (IPTG) and $25{ }^{\circ} \mathrm{C}$ is the optimal inducement condition for $\mathrm{X}_{\mathrm{CAS}}$ production, and almost all of the target proteins were expressed in soluble form (Supplementary Figure S1B). The soluble fraction of the expressed protein was purified as described in Materials and Methods and analyzed by SDS-PAGE. As shown in Figure 1, the purified protein had a molecular mass of approximately $66.2 \mathrm{kDa}$.

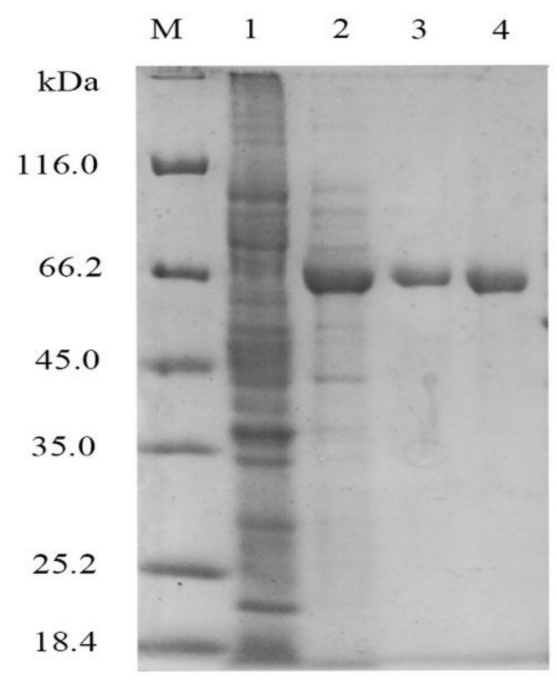

Figure 1. SDS-PAGE analysis of expressed Xanthomonas campestris pv. campestris (XcAS). Lane M shows the protein molecular weight marker; lane 1 shows total protein of E. coli JM109 cells harboring pET28a plasmid; lane 2 shows soluble supernatant of $E$. coli JM109 cells harboring the recombinant pET28a-xcas plasmid; lane 3 shows purified XcAS; and lane 4 shows purified XcAS after ultrafiltration.

\subsection{Bioconversion of $H Q$ to $\alpha$-Arbutin by Purified XcAS}

The transglucosylation reaction was performed using sucrose as a glucosyl donor and $10 \mathrm{mM}$ hydroquinone as an acceptor in $50 \mathrm{mM}$ phosphate buffer (Supplementary Figure S3A). It is known that benzoquinone, produced by the oxidation of hydroquinone, can inhibit the enzyme activity by chemically modifying and reducing its stability [9]. Thus, ascorbic acid (VC) was added to the reaction system to inhibit the oxidation of hydroquinone and improve the bioconversion rate of $\alpha$-arbutin. After the reaction, the sample was analyzed by HPLC. As shown in Supplementary Figure S3B, there were two peaks at retention times (tR) of $4.5 \mathrm{~min}$ and $5.8 \mathrm{~min}$, corresponding to $\alpha$-arbutin and $\mathrm{HQ}$, respectively.

\subsection{Catalysis Characterization of Purified XcAS on Transglucoside Reaction}

The influence of $\mathrm{pH}$ and temperature on the transglucoside activity of recombinant XcAS was determined by using sucrose as a glycosyl donor and hydroquinone as an acceptor. As shown in Figure $2 \mathrm{~A}$, the enzyme had optimal activity between $\mathrm{pH}$ values of 6.0 and 7.5 , with specific activity of $0.9 \mathrm{U} / \mathrm{mg}$. Moreover, in a $\mathrm{pH}$ stability assay (Figure 2B), XcAS transglucoside activity showed a slight reduction in $\mathrm{pH}$ in the range of 5.5-8.0 after being incubated in different $\mathrm{pH}$ at $4{ }^{\circ} \mathrm{C}$. As shown in Figure $2 \mathrm{C}$, the maximal transglucoside activity of the recombinant $\mathrm{XcAS}_{\mathrm{C}}$ was at $30^{\circ} \mathrm{C}$. Furthermore, thermal stability analysis indicated that the enzyme was stable from 20 to $30^{\circ} \mathrm{C}$. However, the activity of XcAS decreased sharply when the temperature increased above $35^{\circ} \mathrm{C}$ (Figure 2D). The kinetics of the XcAS-catalyzed transglucoside reaction was tested at the optimal $\mathrm{pH}$ and temperature using sucrose as a glucosyl donor and hydroquinone as an acceptor. As shown in Figure 3, the $K_{m}$ and $V_{\max }$ values of the XcAS-catalyzed reaction were $11.29 \pm 0.43 \mathrm{mM}$ and $2.49 \pm 0.04 \mathrm{U} / \mathrm{mg}$, respectively. 
(A)
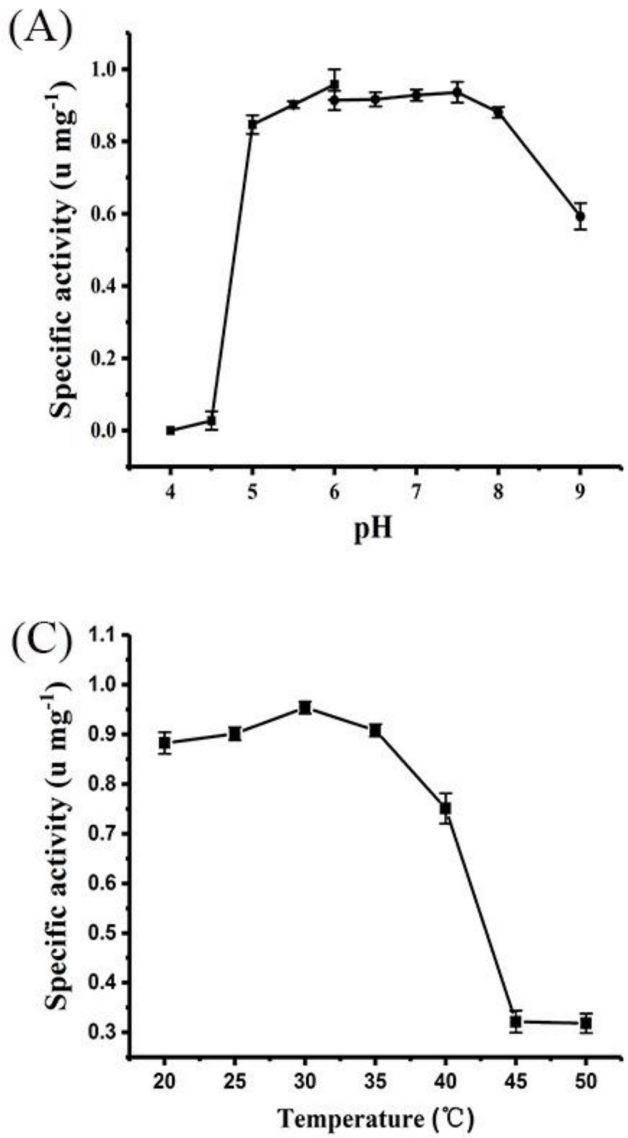

(B)

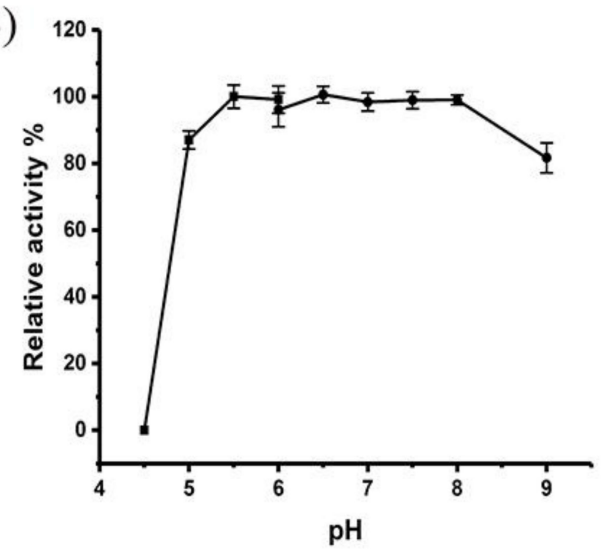

(D)

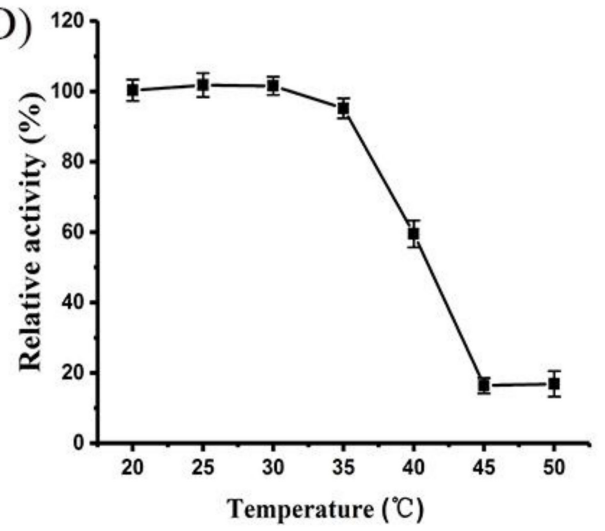

Figure 2. Effects of $\mathrm{pH}$ and temperature on purified $\mathrm{X}_{\mathrm{CAS}}$ transglucoside activity and stability. (A) Specific activity of XcAS at different external $\mathrm{pH}$. Assays were performed at $30{ }^{\circ} \mathrm{C}$ in $50 \mathrm{mM}$ citrate buffer (pH 4.0-6.0) and $50 \mathrm{mM}$ sodium phosphate buffer (pH 6.0-9.0). (B) pH stability of XcAS. Purified XCAS was preincubated at $\mathrm{pH}$ varying from 4.5 to 9.0 for $24 \mathrm{~h}$ at $4{ }^{\circ} \mathrm{C}$ before enzyme activity was measured. (C) Specific activity of $\mathrm{X}_{\mathrm{C}} \mathrm{AS}$ at different temperatures. Tests were performed at $\mathrm{pH} 7.0$ in $50 \mathrm{mM}$ sodium phosphate buffer. (D) Enzyme stability of XcAS at different temperatures. Assays were performed after preincubating XcAS for $1 \mathrm{~h}$ at different temperatures.
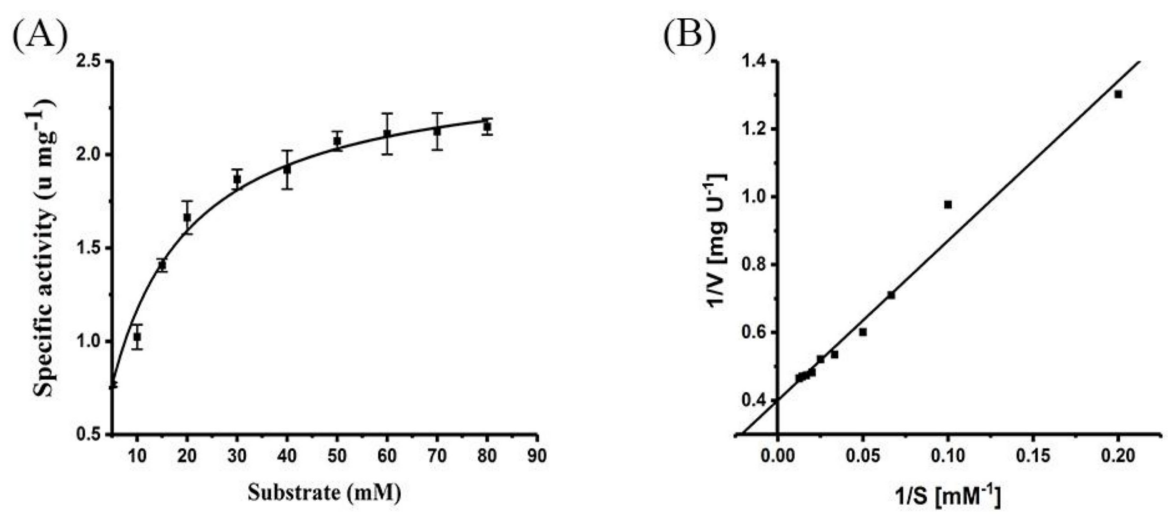

Figure 3. Determination of kinetic parameters of XcAS-catalyzed transglucoside reaction: (A) Michaelis-Menten plot and (B) double-reciprocal plot. Reactions were carried out at $\mathrm{pH} 7.0$ and $30^{\circ} \mathrm{C}$ by adding various amount of sucrose and hydroquinone (HQ) (ratio 10:1) to $50 \mathrm{mM}$ sodium phosphate buffer. 


\subsection{Effects of $\mathrm{pH}$ and Temperature on $\alpha$-Arbutin Production by Whole-Cell Biocatalysis}

Bioconversion of $\alpha$-arbutin from HQ by whole-cell biocatalysis is a favorable approach with many advantages $[7,21]$. Thus far, $\alpha$-arbutin production yield is limited by the low level of enzyme activity, and research on high substrate concentration for $\alpha$-arbutin production is still lacking. In the present study, E. coli JM109/pet28a-xcas with a high activity of amylosucrase, as described above, was used for the bioconversion of $\mathrm{HQ}$ to $\alpha$-arbutin. Furthermore, the biotransformation conditions were optimized.

To optimize the efficiency of whole-cell biocatalysis on $\alpha$-arbutin production, the effects of $\mathrm{pH}$ and temperature were investigated. As illustrated in Figure 4A, a reaction mixture containing $20 \mathrm{~g} / \mathrm{L}$ wet cell weight (WCW) of the culture, $167 \mathrm{mM}$ of HQ, and $1 \mathrm{M}$ of sucrose in $10 \mathrm{~mL}$ of phosphate buffer ( $50 \mathrm{mM}, \mathrm{pH} 7.0$ ) was incubated for $12 \mathrm{~h}$ under a broad range of temperatures $\left(20\right.$ to $40{ }^{\circ} \mathrm{C}$ ). The results showed that the highest conversion rate of $\mathrm{HQ}$ was $80.4 \%$ at $30{ }^{\circ} \mathrm{C}$, which can be used as the optimal temperature for whole-cell biocatalysis. As the temperature increased from 30 to $40^{\circ} \mathrm{C}$, the conversion rate reduced dramatically, suggesting that XcAS activity was low and unstable at temperatures higher than $30^{\circ} \mathrm{C}$. Additionally, the effect of $\mathrm{pH}$ (range 4-10) was examined on whole-cell biocatalysis. All of the experiments were carried out at $30^{\circ} \mathrm{C}$. At $\mathrm{pH} 7.0$, the maximum conversion rate was obtained, while the production of $\alpha$-arbutin sharply decreased with a slight divergence from the optimal pH (Figure 4B). Thus, the optimum pH value of 7.0 and temperature of $30^{\circ} \mathrm{C}$ were chosen for further experiments.
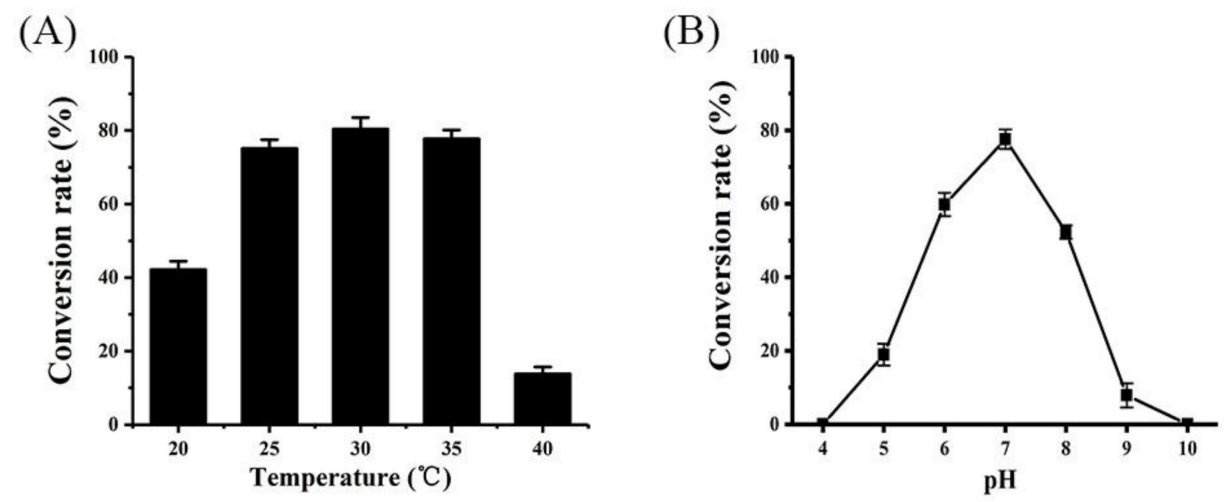

Figure 4. Effects of (A) temperature and (B) $\mathrm{pH}$ on $\alpha$-arbutin conversion rate. All assays were performed in triplicate in three independent experiments. Standard deviations of biological replicates are represented by error bars.

\subsection{Effects of Surfactant and Its Concentration on $\alpha$-Arbutin Production}

Surfactant additives can increase cell membrane permeability and enhance substrate transportation in whole-cell biocatalysis [22]. The effects of different surfactants $(0.1 \% \mathrm{w} / \mathrm{v})$ were investigated on the whole-cell E. coli JM109/pet28a-xcas biocatalyst system (Figure 5A). The additives hexadecyl trimethyl ammonium bromide (CTAB) and sodium dodecyl sulfate (SDS) strongly inhibited the production of $\alpha$-arbutin, whereas Tween-20, Tween-60, Tween-80, and TritonX-100 significantly improved its conversion rate. Of these surfactants, TritonX-100 had the greatest impact on conversion rate $(90.6 \%), 115 \%$ higher than control, thus it was selected for further research.

To improve $\alpha$-arbutin production, the effect of TritonX-100 concentration was further investigated. The results demonstrated that the conversion rate of $\mathrm{HQ}$ increased, attaining the highest value of $0.4 \%$ $(\mathrm{w} / \mathrm{v})$ with TritonX-100 induction (Figure 5B). However, the conversion rate decreased rapidly when a higher concentration of surfactant was added. Therefore, the optimal TritonX-100 concentration of $0.4 \%(\mathrm{w} / \mathrm{v})$ was used for $\alpha$-arbutin production, with a high conversion rate of $94.5 \%$. 

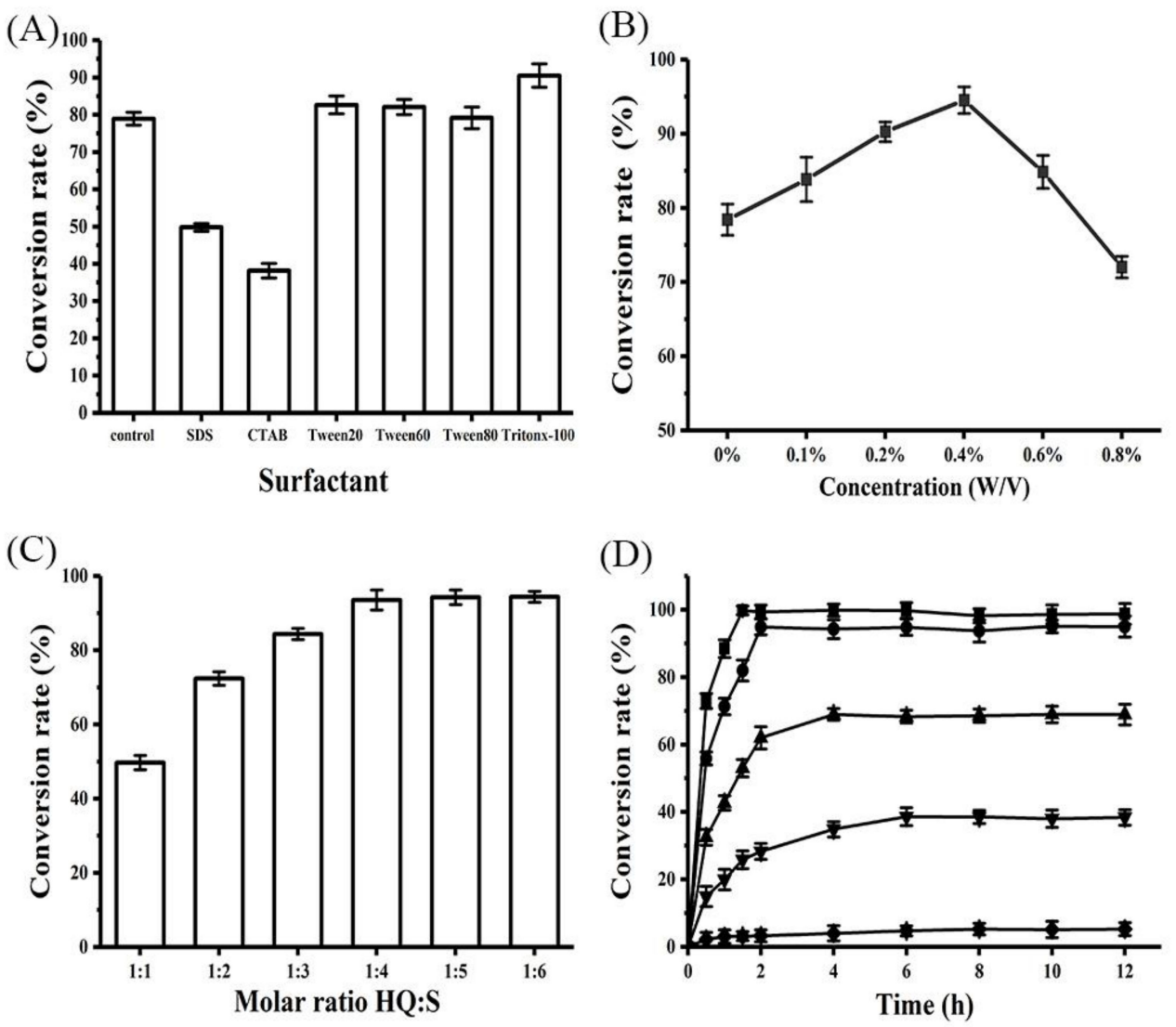

Figure 5. Effects of (A) surfactant, (B) surfactant concentration, (C) substrate ratio, and (D) substrate concentration on $\alpha$-arbutin production: $125 \mathrm{mM}$ (filled squares); $167 \mathrm{mM}$ (filled circles); $208 \mathrm{mM}$ (filled triangles); $250 \mathrm{mM}$ (filled inverted triangles); $292 \mathrm{mM}$ (filled diamonds). All assays were performed in triplicate in three independent experiments. Standard deviations of biological replicates are represented by error bars.

\subsection{Effects of Substrate Ratio and Concentration on $\alpha$-Arbutin Production}

Enzymatic synthesis of $\alpha$-arbutin from sucrose and HQ by E. coli JM109/pet28a-xcas is a one-step stereospecific reaction and its theoretical molar ratio is 1:1 [11]. The effect of the molar ratio of sucrose to HQ on $\alpha$-arbutin production was investigated with $165 \mathrm{mM} H Q$ in this study. When both substrates were in the same ratio (1:1), the conversion rate was only $49.7 \%$ (Figure 5C). By increasing the sucrose:HQ ratio to $4: 1$, the conversion rate increased to $93.5 \%$. However, with further increases of the molar ratio to $5: 1$ and 6:1, the conversion rates remained approximately the same, indicating that the amylosucrase in E. coli JM109/pet28a-xcas was probably saturated with sucrose.

HQ can induce apoptosis in vivo through a change in cellular redox status, especially by reducing the endogenous thiol level and increasing the reactive oxygen species level $[7,23]$. If the concentration of HQ exceeds a certain value, the production of $\alpha$-arbutin may drop sharply due to cell apoptosis. In this study, a series of HQ concentrations were tested and the time courses for these reactions were evaluated at the substrate ratio of 4:1. As shown in Figure 5D, $125 \mathrm{mM}$ of HQ was completely converted within $2 \mathrm{~h}$ and the production of $\alpha$-arbutin attained $34.1 \mathrm{~g} / \mathrm{L}$. Notably, the molar production yields of $\alpha$-arbutin gradually decreased and the reaction time was extended with increasing concentration of HQ. In particular, the conversion rate decreased to $68 \%$ within $6 \mathrm{~h}$ after $208 \mathrm{mM}$ of HQ was added. These results clearly demonstrate that the maximum HQ tolerance of E. coli JM109/pet28a-xcas was $208 \mathrm{mM}$. Furthermore, all the conversion rates retained their maximum values within $12 \mathrm{~h}$. 


\subsection{Efficient Production of $\alpha$-Arbutin through a Batch and Fed-Batch Strategy}

Based on the aforementioned optimal conditions, a total yield of $33.8 \mathrm{~g} / \mathrm{L} \alpha$-arbutin was obtained from $13.7 \mathrm{~g} / \mathrm{L}$ of HQ within $2 \mathrm{~h}$ using the whole-cell E. coli JM109/pet28a-xcas biocatalyst system (Figure 6A). The productivity and conversion yield were $16.9 \mathrm{~g} / \mathrm{L} / \mathrm{h}$ and $99.4 \%$, respectively. No byproduct was detected during the bioconversion process, indicating that XcAS displayed region-selective activity.
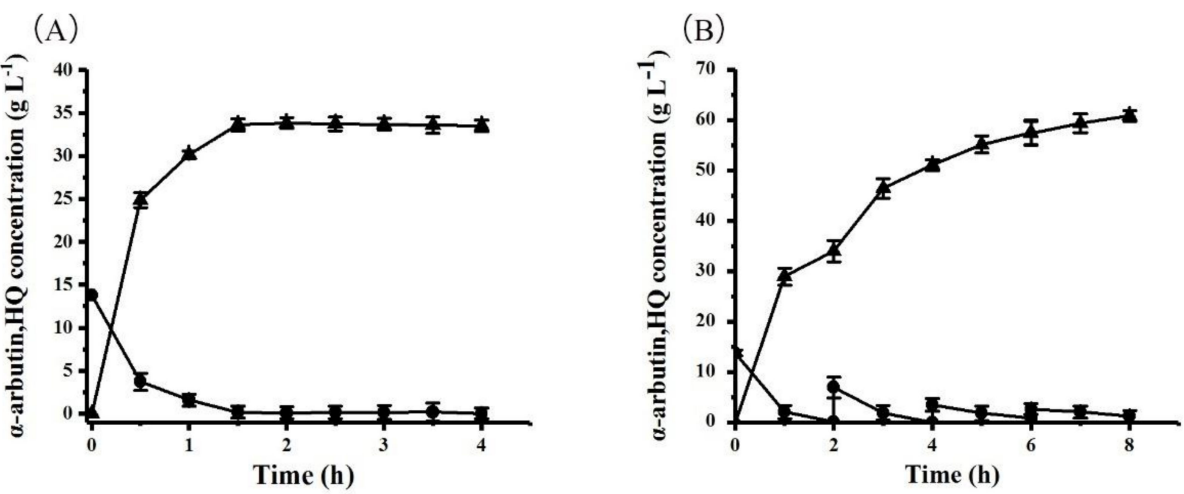

Figure 6. Time course for (A) batch and (B) fed-batch bioconversion of HQ to $\alpha$-arbutin. Filled triangles represent concentration of $\alpha$-arbutin; filled circles represent concentration of HQ.

A fed-batch strategy can improve the final concentration of the desired products [24]. A gradient decreasing batch was used to attain higher $\alpha$-arbutin production for the sake of cell apoptosis induced by high HQ concentration. The initial concentration of HQ was $13.8 \mathrm{~g} / \mathrm{L}(125 \mathrm{mM})$, and decreasing amounts of HQ (i.e., $62.5 \mathrm{mM}, 31.25 \mathrm{mM}$, and $15.62 \mathrm{mM}$ ) and sucrose (molar ratio of HQ:sucrose was 1:4) were added to the conversion system every $2 \mathrm{~h}$. After $8 \mathrm{~h}$ of conversion, the final $\alpha$-arbutin yield reached $60.9 \mathrm{~g} / \mathrm{L}, 180 \%$ higher than before (Figure $6 \mathrm{~B}$ ). More importantly, the final molar yield of $\alpha$-arbutin reached $95.5 \%$ with a productivity of $7.6 \mathrm{~g} / \mathrm{L} / \mathrm{h}$, which was the highest compared to other bioconversion methods (Table 1).

Table 1. Comparison of different biocatalysts or fermentative strains for $\alpha$-arbutin production.

\begin{tabular}{|c|c|c|c|c|c|c|}
\hline Strains and Biotransformation Model & Donor & $\begin{array}{l}\text { Biotransformation } \\
\text { Period (h) }\end{array}$ & $\begin{array}{c}\text { Final } \\
\text { Concentration } \\
(\mathrm{g} / \mathrm{L})\end{array}$ & $\begin{array}{l}\text { Molar } \\
\text { Yield } \\
(\%)\end{array}$ & $\begin{array}{l}\text { Productivity } \\
\text { (g/L/h) }\end{array}$ & Reference \\
\hline \multicolumn{7}{|l|}{ Biocatalysis } \\
\hline B. subtilis strain $\mathrm{X}-23$ & Maltopentaose & 0.6 & 1.50 & 24.8 & 0.4 & 13 \\
\hline Xanthomonas maltophilia BT-112 & Sucrose & 48 & 65.9 & 95.2 & 1.4 & 7 \\
\hline $\begin{array}{c}\text { Escherichia coli JM109 (Amylosucrase) } \\
\text { Enzymatic catalysis }\end{array}$ & Sucrose & 8 & 60.9 & 95.5 & 7.6 & This study \\
\hline Amylosucrase (Deinococcus geothermalis) & Sucrose & 24 & 5.78 & 90 & 0.24 & 11 \\
\hline$\alpha$-Glucosidase (Saccharomyces cerevisiae) & Maltose & 20 & 1 & 4.6 & 0.05 & 9 \\
\hline $\begin{array}{c}\text { Dextransucrase (Leuconostoc mesenteroides) } \\
\text { Fermentation }\end{array}$ & Sucrose & 6 & 0.544 & 0.4 & 0.09 & 14 \\
\hline Escherichia coli BL21 ( $\alpha$-glucosidase) & Maltose & 36 & 21 & 76 & 0.58 & 25 \\
\hline Xanthomonas maltophilia BT-112 & Sucrose & 72 & 61.7 & 94.5 & 0.86 & 8 \\
\hline
\end{tabular}

Biocatalysis is the transformation carried out using whole cells; enzymatic catalysis is the transformation carried out by purified enzyme; fermentation is the transformation carried out with fermentative strains.

\section{Discussion}

Amylosucrase is a multifunctional enzyme from the glycoside hydrolase family 13 that has powerful transglucosylation activity to generate $\alpha-1,4$-linked glucose-transfer products from sucrose as glucoside donor [17]. To date, ASase from Deinococcus geothermalis (DG-ASase) [11,25] and Cellulomonas carbonis (CC-ASase) [12] has been reported to synthesize $\alpha$-arbutin via the transglucosylation of inexpensive sucrose as glucosyl donor and HQ as glucosyl receptor. Compared 
with other glycosyltransferases, amylosucrase does not require the addition of expensive activated sugars and exhibits predominant biotransformation ability and higher efficiency in the glycosylation of HQ (Table 1). In this study, we first employed an ASase from X. campestris pv. campestris (XcAS) as the catalyst to synthesize $\alpha$-arbutin. The commercial expression vector pet28a+, containing an induced expression system, was used for heterologous expression of XcAS in E. coli JM109 (DE3). The transcriptional expression was controlled by the lac repressor, thus required IPTG as an inducer. The initial recombinant protein was mainly found in IBs (Supplementary Figure S1A) and displayed low enzymatic activity. Previous studies have reported that the heterologous protein, with a high molecular weight and complicated structure, further impedes the capacity of host cells to fold the protein intermediates, and results in the formation of IBs [26]. As a consequence, we optimized the temperature and IPTG concentrations for amylosucrase expression. The highest intracellular hydrolysis activity of $5.0 \mathrm{U} / \mathrm{mg}$ was obtained at a low temperature $\left(25^{\circ} \mathrm{C}\right)$ and IPTG concentration of $0.1 \mathrm{mM}$, and almost no IBs were seen in the expression results (Supplementary Figures S1B and S2). These phenomena can be explained by the reduced IB formation due to the proper folding of precursor proteins under low temperature and low inducer concentration $[27,28]$.

The catalytic property of XcAS in the transglucoside reaction was studied by using sucrose as the glucoside donor and $\mathrm{HQ}$ as the receptor. The optimal $\mathrm{pH}$ of $\mathrm{X}_{\mathrm{CAS}}$ transglucosylation activity was in the range of 6.0-7.5 (Figure 2A) and the enzyme maintained stability between pH 5.5 and 8.0 (Figure 2B). It is assumed that the optimum working condition of this enzyme is neutral, which is similar to that of ASase from Deinococcus geothermalis ( $\mathrm{pH}$ 7.0) [11], Cellulomonas carboni (pH 7.0) [12], and Truepera radiovictrix ( $\mathrm{pH}$ 7.5) [29]. The maximal transglucosylation activity was obtained at $30{ }^{\circ} \mathrm{C}$ (Figure 2C) and dropped rapidly when the temperature was higher than $35^{\circ} \mathrm{C}$ (Figure 2D). It appeared that the enzyme obtained in this study showed low thermal stability, which is a little different from CC-ASase $\left(40^{\circ} \mathrm{C}\right)$ and DG-ASase $\left(45^{\circ} \mathrm{C}\right)$. Furthermore, the apparent $\mathrm{K}_{\mathrm{m}}$ and $\mathrm{V}_{\max }$ values of the XcAS-catalyzed transglucoside reaction using $\mathrm{HQ}$ as acceptor were $11.29 \pm 0.43 \mathrm{mM}$ and $2.49 \pm 0.04 \mathrm{U} / \mathrm{mg}$, respectively (Figure 3 ). This suggests that $\mathrm{XCAS}_{\mathrm{C}}$ has potential application in $\alpha$-arbutin biosynthesis.

Recently, whole-cell biocatalyst has been widely used in the industrial production of glycosides, due to its efficient biotransformation process and simplified downstream purification procedure [30]. In our work, the resting cells of recombinant $E$. coli JM109/pet28a-xcas were prepared as a whole-cell biocatalyst in order to synthesize $\alpha$-arbutin from HQ. By optimizing the biocatalysis conditions with the addition of TritonX-100 surfactant and using an HQ concentration of $125 \mathrm{mM}$, the production yield, conversion rate, and productivity of $\alpha$-arbutin were found to be $33.8 \mathrm{~g} / \mathrm{L}, 99.4 \%$, and $16.9 \mathrm{~g} / \mathrm{L} / \mathrm{h}$, respectively. Compared with other surfactants, TritonX-100 can obviously increase the conversion rate of $\alpha$-arbutin, while SDS and CTAB have an inhibitory effect on whole-cell biocatalyst (Figure 5A). It appeared that much of this loss of amylosucrase enzymatic activity caused by ionic surfactants was due to the destruction of XcAS, while nonionic surfactants stimulated the reaction by increasing cell membrane permeability without affecting enzyme activity. In addition, the biocatalytic ability of E. coli JM109/pet28a-xcas cells was inhibited by a high HQ concentration (208 mM), which is consistent with previous studies $[6,7,11,12]$. A high concentration of HQ may induce cell apoptosis by changing intracellular redox status through decreasing the thiol level and increasing the reactive oxygen species level [31,32]. To prevent the toxicity of high HQ concentration while retaining $\alpha$-arbutin production yield, a gradient decreasing fed-batch strategy was applied. As a result, the final production yield and molar conversion yield of $\alpha$-arbutin reached $60.9 \mathrm{~g} / \mathrm{L}$ and $95.5 \%$, respectively, with an $\mathrm{HQ}$ concentration of $234.4 \mathrm{mM}$ (Figure 6B). Furthermore, the highest productivity of $\alpha$-arbutin $(7.6 \mathrm{~g} / \mathrm{L} / \mathrm{h}$ ) was obtained, which was five-fold higher than the previously reported value $(<1.4 \mathrm{~g} / \mathrm{L} / \mathrm{h})$.

Overall, our findings suggest that recombinant E. coli JM109/pet28a-xcas may be used as whole-cell biocatalyst system to produce $\alpha$-arbutin from HQ. Furthermore, a high conversion rate in this system can simplify the downstream processing of $\alpha$-arbutin purification. Hence, the proposed method may have potential applications for $\alpha$-arbutin synthesis in the pharmaceutical and cosmetic industries. 


\section{Materials and Methods}

\subsection{Microorganism Plasmids and Chemicals}

HQ, sucrose, and ascorbic acid (VC) were purchased from Sinopharm Chemical Reagent Co., Ltd. (Shanghai, China). $\alpha$-Arbutin standards were purchased from Sigma-Aldrich (St. Louis, MO, USA). Restriction endonucleases, Pfu DNA polymerase, and In-Fusion Cloning Kit were purchased from Vazyme Biotech Co., Ltd. (Nanjing, China). Escherichia coli DH5 $\alpha$ was used (primary host) for the construction of pet28a ${ }^{+}$-xcas. E. coli JM109*[DE3] (recA1 supE44 endA1 hsdR17 (rk- mk+) gyrA96 thi $\Delta$ (lac-proAB) $\mathrm{F}^{\prime}[\operatorname{traD} 36$ proAB laclqZ $\Delta \mathrm{M} 15]$ IDE3) was used as a host for pet28a ${ }^{+}$-xcas to express the ASase gene.

\subsection{Cloning and Recombinant Expression of ASase Gene from X. campestris pv. campestris}

The full nucleotide sequence of ASase-encoding gene (GeneBank NC_003902.1, region: 40023-4004221) from X. campestris pv. campestris str. ATCC 33913 was commercially synthesized by Genewize Co., Ltd (Suzhou, China). The resultant plasmid pUC 57-xcas was used as a template to amplify the amylosucrase gene. Primers used in this study were as follows: As-F (5'-cgcggcagccatatgg ctagcATGATCGCTTCCTCCCCCA-3') and As-R (5'-tggtggtggtggtgctcgagTCAACGACGCTGCAA CCAG-3'). The PCR product was inserted into pET-28a+ using In-Fusion ${ }^{\circledR}$ clone at NheI and XhoI sites, resulting in the expression vector of pET28a-xcas. The vector was then transformed into $E$. coli JM109*[DE3] cells for expression studies. Recombinant E. coli cells were grown in $50 \mathrm{~mL}$ Terrific Broth (TB) medium (11.8 g/L tryptone, $23.6 \mathrm{~g} / \mathrm{L}$ yeast extract, $9.4 \mathrm{~g} / \mathrm{L}$ dipotassium hydrogen phosphate, $2.2 \mathrm{~g} / \mathrm{L}$ potassium dihydrogen phosphate, $4 \mathrm{~mL}$ glycerol $(0.4 \%))$ containing $0.1 \mathrm{mg} / \mathrm{mL}$ kanamycin. Protein expression was induced with isopropyl $\beta$-D-1-thiogalactopyranoside (IPTG) at OD600 values of 1.0-1.2. After $24 \mathrm{~h}$ of induction, the cells were harvested by centrifugation at $7000 \times \mathrm{g}$ for $20 \mathrm{~min}$ at $4{ }^{\circ} \mathrm{C}$. The resultant cell pellet was resuspended in $50 \mathrm{mM}$ phosphate buffered saline (PBS) (50 $\mathrm{mM} \mathrm{NaH}_{2} \mathrm{PO}_{4}$, $50 \mathrm{mM} \mathrm{Na}_{2} \mathrm{HPO}_{4}, 0.9 \% \mathrm{NaCl}, \mathrm{pH} 7.0$ ) and sonicated for $10 \mathrm{~min}$ in an ice-water bath. The lysate was centrifuged at 10,000 rpm for $10 \mathrm{~min}$ at $4{ }^{\circ} \mathrm{C}$. Supernatant was collected as the intracellular fraction.

\subsection{Protein Purification}

To obtain the purified XcAS, the supernatant was filtered through a $0.45 \mu \mathrm{m}$ filter and loaded into an $\mathrm{Ni}^{2+}$-chelating Sepharose Fast Flow column (Uppsala, Sweden). The column was balanced by $50 \mathrm{mM}$ sodium phosphate buffer (pH 7.0) containing $500 \mathrm{mM} \mathrm{NaCl}$ and washed with the same buffer containing $50 \mathrm{mM}$ imidazole after protein loading. The bound protein was eluted with $50 \mathrm{mM}$ sodium phosphate buffer ( $\mathrm{pH} 7.0$ ) containing $500 \mathrm{mM}$ imidazole and $500 \mathrm{mM} \mathrm{NaCl}$. The active fractions were collected and concentrated using Amicon Ultra-15 (Millipore) with a pore size of $30 \mathrm{kDa}$. All of the purification processes were performed at $4{ }^{\circ} \mathrm{C}$ [33].

\subsection{Enzymatic Activity Assay and SDS-PAGE}

Determination of ASase hydrolysis activity was carried out on the basis of the hydrolysis reaction of sucrose. The fructose and glucose concentrations were determined by the 3,5-dinitrosalicylic (DNS) acid method [20]. The reaction was initiated by adding $50 \mu \mathrm{L}$ of the enzyme solution in a reaction mixture with $100 \mu \mathrm{L}$ of $200 \mathrm{mM}$ sucrose, then incubated for $10 \mathrm{~min}$ at $37^{\circ} \mathrm{C}$. Subsequently, the reaction was terminated by adding $200 \mu \mathrm{L}$ DNS solution and then incubated at $100{ }^{\circ} \mathrm{C}$ for $5 \mathrm{~min}$. The resultant mixture was measured at $545 \mathrm{~nm}$ to determine the total reducing sugar, and fructose was used as a standard. One unit of enzymatic hydrolysis activity was defined as the amount of enzyme required to hydrolyze $1 \mu \mathrm{mol}$ of sucrose per minute in standard assay conditions.

ASase transglucosylation activity was assayed using sucrose as glucosyl donor and $\mathrm{HQ}$ as acceptor. The $1 \mathrm{~mL}$ mixture containing $70 \mu \mathrm{g} / \mathrm{mL}$ XcAS, $50 \mathrm{mM}$ sucrose, $1 \mathrm{mM} \mathrm{VC}$, and $10 \mathrm{mM}$ HQ in $50 \mathrm{mM}$ phosphate buffer was incubated at $30{ }^{\circ} \mathrm{C}$ for $2 \mathrm{~h}$ [12]. One unit of transglucosylation activity was defined as the amount of enzyme required to produce $1 \mu \mathrm{mol}$ of $\alpha$-arbutin per minute in the assay 
conditions. Meanwhile, the soluble expression of ASase in E. coli JM109*[DE3] cells was analyzed with SDS-PAGE [24].

$$
\text { Specific activity }(\mathbf{U} / \mathbf{m g})=\frac{\text { Total enzyme activity }(\mathbf{U})}{\text { Purified protein }(\mathbf{m g})}
$$

\subsection{Enzyme Properties of Purified XcAS on Transglucosylation}

The optimal $\mathrm{pH}$ of $\mathrm{XcAS}$ was determined in citrate/phosphate buffer from 4.0 to 9.0 at $30^{\circ} \mathrm{C}$. To measure the $\mathrm{pH}$ stability, the purified XcAS was preincubated at various levels ( $\mathrm{pH}$ 4.5-9.0) for $24 \mathrm{~h}$ at $4{ }^{\circ} \mathrm{C}$ before enzyme activity was measured. The optimal temperature was measured from 20 to $50{ }^{\circ} \mathrm{C}$ at $\mathrm{pH}$ 7.0. To determine the thermostability of the purified XcAS, the enzyme was incubated at different temperatures for $1 \mathrm{~h}$ at $\mathrm{pH} 7.0$ buffer [34].

Kinetic assays of XcAS transglucosylation were performed under the condition of optimal temperature and $\mathrm{pH}$ with sucrose $(25-400 \mathrm{mM})$ and $\mathrm{HQ}(5-80 \mathrm{mM})$ as substrates. The kinetic parameters, $K_{m}$ and $V_{\max }$, were determined by the Lineweaver-Burk plotting method [33]. The equation was as follows:

$$
\frac{1}{\mathbf{V}}=\frac{\mathbf{K m}}{\mathbf{V m a x}} \times \frac{1}{[\mathbf{S}]}+\frac{1}{\mathbf{V m a x}}
$$

where $\mathrm{V}$ indicates the reaction rate, $\mathrm{K}_{\mathrm{m}}$ is the Michaelis-Menten constant, $\mathrm{V}_{\max }$ is the maximum reaction rate, and $[S]$ is the substrate concentration.

\subsection{Bioconversion of $H Q$ to $\alpha$-Arbutin by Whole-Cell Biocatalysis}

Recombinant E. coli JM109*[DE3]/pET28a-xcas strain was grown in $50 \mathrm{~mL}$ TB medium at different temperatures, and induced with IPTG for $12 \mathrm{~h}$. The cells were harvested by centrifugation at $7000 \mathrm{rpm}$ for $20 \mathrm{~min}$, and washed twice with $50 \mathrm{mM}$ PBS (pH 7.0). Then, the cells were resuspended with $10 \mathrm{~mL}$ of $50 \mathrm{mM}$ PBS (pH 7.0) containing HQ (glucosyl acceptor) and sucrose (glucosyl donor). To increase production yield, ascorbic acid was added to the reaction mixture at a final concentration of $1 \mathrm{mM}$ to prevent oxidation of hydroquinone [11]. Whole-cell biocatalysis was performed on a rotary shaker $(200 \mathrm{rpm})$ at $30^{\circ} \mathrm{C}$, unless otherwise mentioned. The biocatalysis product was harvested by centrifugation for $10 \mathrm{~min}$ at 12,000 rpm, followed by HPLC analysis.

\subsection{Analytical Methods}

The amount of $\alpha$-arbutin was determined by HPLC on an Eclipse XDB-C18 column $(4.6 \times 250 \mathrm{~mm} ; 45$ $\left.{ }^{\circ} \mathrm{C}\right)$ connected to an SPD-10A UV detector $(280 \mathrm{~nm})$ and SPD-LC10 pump. The separation of $\alpha$-arbutin was carried out using methanol and water $(9: 1 \mathrm{v} / \mathrm{v})$ as the mobile phase at a flow rate of $0.8 \mathrm{~mL} \mathrm{~min}{ }^{-1}$ with a column temperature of $45^{\circ} \mathrm{C}$ [11]. The conversion rate of $\alpha$-arbutin is given by:

$$
\mathbf{n}(\%)=\frac{\mathrm{M}_{1}}{\mathrm{M}_{2}} \times 100 \%
$$

where $\mathrm{M}_{1}$ is the mole of $\mathrm{HQ}$ before transformation and $\mathrm{M}_{2}$ is the mole of $\alpha$-arbutin after transformation.

Supplementary Materials: The following are available online at http:/ /www.mdpi.com/2073-4344/9/1/5/s1, Figure S1: SDS-PAGE analysis of XcAS expression in E. coli JM109[DE3] (A) before and (B) after process condition optimization, Figure S2: Effects of (A) temperature and (B) IPTG concentration on E. coli cell growth and XcAS hydrolysis activity in E. coli JM109/pet28a-xcas, Figure S3: Structural determination of the transglucosylated product.

Author Contributions: Conceptualization, J.S. and B.Z.; Data curation, C.Y. and R.Z.; Formal analysis, C.Y. and B.Z.; Funding acquisition, B.Z.; Investigation, C.Y. and W.F.; Methodology, C.Y. and R.Z.; Project administration, W.F. and J.S.; Writing-original draft, C.Y.; Writing—review and editing, Z.K.-J. and B.Z.

Funding: This research was funded by the grants from the State Key Project of Research and Development Plan (grant number: 2017YFE0112700). This work was partly supported by the National Natural Science Foundation of China (grant number: 41106125). 
Acknowledgments: We thank Junsong Sun (Shanghai Advanced Research Institute, Chinese Academy of Sciences) for valuable suggestions on the manuscript.

Conflicts of Interest: The authors declare no conflict of interest.

\section{References}

1. Seo, D.H.; Jung, J.H.; Lee, J.E.; Jeon, E.J.; Kim, W.; Park, C.S. Biotechnological production of arbutins (alphaand beta-arbutins), skin-lightening agents, and their derivatives. Appl. Microbiol. Biotechnol. 2012, 95, 1417-1425. [CrossRef] [PubMed]

2. Sugimoto, K.; Nishimura, T.; Nomura, K.; Sugimoto, K.; Kuriki, T. Inhibitory effects of alpha-arbutin on melanin synthesis in cultured human melanoma cells and a three-dimensional human skin model. Biol. Pharm. Bull. 2004, 27, 510-514. [CrossRef]

3. Funayama, M.; Arakawa, H.; Yamamoto, R.; Nishino, T.; Shin, T.; Murao, S. Effects of alpha- and beta-arbutin on activity of tyrosinases from mushroom and mouse melanoma. Biosci. Biotechnol. Biochem. 1995, 59, 143-144. [CrossRef] [PubMed]

4. Nishimura, T.; Kometani, T.; Takii, H.; Terada, Y.; Okada, S. Purifiction and some properties of alpha-amylase from bacillus-subtilis X-23 that glucosylates phenolic-compounds such as hydroquinone. J. Ferment. Bioeng. 1994, 78, 31-36. [CrossRef]

5. Kurosu, J.; Sato, T.; Yoshida, K.; Tsugane, T.; Shimura, S.; Kirimura, K.; Kino, K.; Usami, S. Enzymatic synthesis of alpha-arbutin by alpha-anomer-selective-glucosylation of hydroquinone using lyophilized cells of Xanthomonas campestris WU-9701. J. Biosci. Bioeng. 2002, 93, 328-330. [CrossRef]

6. Liu, C.Q.; Deng, L.; Zhang, P.; Zhang, S.R.; Liu, L.; Xu, T.; Wang, F.; Tan, T.W. Screening of high alpha-arbutin producing strains and production of alpha-arbutin by fermentation. World J. Microbiol. Biotechnol. 2013, 29, 1391-1398. [CrossRef] [PubMed]

7. Liu, C.Q.; Deng, L.; Zhing, P.; Zhang, S.R.; Xu, T.; Wang, F.; Tan, T.W. Efficient production of alpha-arbutin by whole-cell biocatalysis using immobilized hydroquinone as a glucosyl acceptor. J. Mol. Catal. B-Enzym. 2013, 91, 1-7. [CrossRef]

8. Liu, C.Q.; Zhang, P.; Zhang, S.R.; Xu, T.; Wang, F.; Deng, L. Feeding strategies for the enhanced production of alpha-arbutin in the fed-batch fermentation of Xanthomonas maltophilia BT-112. Bioprocess. Biosyst. Eng. 2014, 37, 325-329. [CrossRef]

9. Prodanovic, R.; Milosavic, N.; Sladic, D.; Zlatovic, M.; Bozic, B.; Velickovic, T.C.; Vujcic, Z. Transglucosylation of hydroquinone catalysed by alpha-glucosidase from baker's yeast. J. Mol. Catal. B-Enzym. 2005, 35, 142-146. [CrossRef]

10. Sato, T.; Hasegawa, N.; Saito, J.; Umezawa, S.; Honda, Y.; Kino, K.; Kirimura, K. Purification, characterization, and gene identification of an alpha-glucosyl transfer enzyme, a novel type alpha-glucosidase from Xanthomonas campestris WU-9701. J. Mol. Catal. B-Enzym. 2012, 80, 20-27. [CrossRef]

11. Seo, D.H.; Jung, J.H.; Ha, S.J.; Cho, H.K.; Jung, D.H.; Kim, T.J.; Baek, N.I.; Yoo, S.H.; Park, C.S. High-yield enzymatic bioconversion of hydroquinone to alpha-arbutin, a powerful skin lightening agent, by amylosucrase. Appl. Microbiol. Biotechnol. 2012, 94, 1189-1197. [CrossRef] [PubMed]

12. Yu, S.H.; Wang, Y.C.; Tian, Y.Q.; Xu, W.; Bai, Y.X.; Zhang, T.; Mu, W.M. Highly efficient biosynthesis of alpha-arbutin from hydroquinone by an amylosucrase from Cellulomonas carboniz. Process Biochem. 2018, 68, 93-99. [CrossRef]

13. Kitao, S.; Sekine, H. Alpha-D-Glucosyl Transfer to Phenolic Compounds by Sucrose Phosphorylase from Leuconostoc mesenteroides and Production of alpha-Arbutin. Biosci. Biotechnol. Biochem. 1994, 58, 38-42. [CrossRef] [PubMed]

14. Seo, E.S.; Kang, J.; Lee, J.H.; Kin, G.E.; Kim, G.J.; Kim, D. Synthesis and characterization of hydroquinone glucoside using Leuconostoc mesenteroides dextransucrase. Enzym. Microb. Technol. 2009, 45, 355-360. [CrossRef]

15. Mathew, S.; Adlercreutz, P. Regioselective glycosylation of hydroquinone to $\alpha$-arbutin by cyclodextrin glucanotransferase from Thermoanaerobacter sp. Biochem. Eng. J. 2013, 79, 187-193. [CrossRef]

16. Zhou, X.; Zheng, Y.T.; Wei, X.M.; Yang, K.D.; Yang, X.K.; Wang, Y.T.; Xu, L.M.; Du, L.Q.; Huang, R.B. Sucrose Isomerase and Its Mutants from Erwinia rhapontici Can Synthesise alpha-Arbutin. Protein Pept. Lett. 2011, 18, 1028-1034. [CrossRef] 
17. Tian, Y.; Xu, W.; Zhang, W.; Zhang, T.; Guang, C.; Mu, W. Amylosucrase as a transglucosylation tool: From molecular features to bioengineering applications. Biotechnol. Adv. 2018, 36, 1540-1552. [CrossRef]

18. De Montalk, G.P.; Remaud-Simeon, M.; Willemot, R.M.; Sarcabal, P.; Planchot, V.; Monsan, P. Amylosucrase from Neisseria polysaccharea: Novel catalytic properties. FEBS Lett. 2000, 471, 219-223. [CrossRef]

19. Skov, L.K.; Mirza, O.; Henriksen, A.; De Montalk, G.P.; Remaud-Simeon, M.; Sarcabal, P.; Willemot, R.M.; Monsan, P.; Gajhede, M. Amylosucrase, a glucan-synthesizing enzyme from the alpha-amylase family. J. Biol. Chem. 2001, 276, 25273-25278. [CrossRef]

20. Seo, D.-H.; Jung, J.-H.; Ha, S.-J.; Yoo, S.-H.; Kim, T.-J.; Cha, J.; Park, C.-S. Molecular Cloning of the Amylosucrase Gene from a Moderate Thermophilic Bacterium Deinococcus Geothermalis and Analysis of its Dual Enzyme Activity. Carbohydr. Act. Enzym. 2008, 125-140. [CrossRef]

21. Wu, P.H.; Giridhar, R.; Wu, W.T. Surface display of transglucosidase on Escherichia coli by using the ice nucleation protein of Xanthomonas campestris and its application in glucosylation of hydroquinone. Biotechnol. Bioeng. 2006, 95, 1138-1147. [CrossRef] [PubMed]

22. King, A.T.; Davey, M.R.; Mellor, I.R.; Mulligan, B.J.; Lowe, K.C. Surfactant Effects on Yeast-Cells. Enzym. Microb. Technol. 1991, 13, 148-153. [CrossRef]

23. Khan, S.; Altaf, I.; Rasheed, M.A.; Ashraf, M.; Ishaq, S.; Bashir, R.; Munir, N. Protection of vitamin A and E against toxicity induced by hydroquinone. Indian J. Exp. Biol. 2017, 55, 383-388.

24. Shao, M.; Zhang, X.; Rao, Z.; Xu, M.; Yang, T.; Li, H.; Xu, Z.; Yang, S. Efficient testosterone production by engineered Pichia pastoris co-expressing human 17 $\beta$-hydroxysteroid dehydrogenase type 3 and Saccharomyces cerevisiae glucose 6-phosphate dehydrogenase with NADPH regeneration. Green Chem. 2016, 18, 1774-1784. [CrossRef]

25. Lee, H.S.; Kim, T.S.; Parajuli, P.; Pandey, R.P.; Sohng, J.K. Sustainable Production of Dihydroxybenzene Glucosides Using Immobilized Amylosucrase from Deinococcus geothermalis. J. Microbiol. Biotechnol. 2018, 28, 1447-1456. [PubMed]

26. Ramshini, H.; Parrini, C.; Relini, A.; Zampagni, M.; Mannini, B.; Pesce, A.; Saboury, A.A.; Nemat-Gorgani, M.; Chiti, F. Large Proteins Have a Great Tendency to Aggregate but a Low Propensity to form Amyloid Fibrils. PLoS ONE 2011, 6, e16075. [CrossRef] [PubMed]

27. Jhamb, K.; Sahoo, D.K. Production of soluble recombinant proteins in Escherichia coli: Effects of process conditions and chaperone co-expression on cell growth and production of xylanase. Bioresour. Technol. 2012, 123, 135-143. [CrossRef]

28. Pinsach, J.; de Mas, C.; Lopez-Santin, J.; Striedner, G.; Bayer, K. Influence of process temperature on recombinant enzyme activity in Escherichia coli fed-batch Cultures. Enzym. Microb. Technol. 2008, 43, 507-512. [CrossRef]

29. Zhu, X.; Tian, Y.; Xu, W.; Bai, Y.; Zhang, T.; Mu, W. Biochemical characterization of a highly thermostable amylosucrase from Truepera radiovictrix DSM 17093. Int. J. Biol. Macromol. 2018, 116, 744-752. [CrossRef]

30. Chen, J.Y.; Kaleem, I.; He, D.M.; Liu, G.Y.; Li, C. Efficient production of glycyrrhetic acid 3-O-mono-beta-D-glucuronide by whole-cell biocatalysis in an ionic liquid/buffer biphasic system. Process Biochem. 2012, 47, 908-913. [CrossRef]

31. Shen, D.X.; Shi, X.; Wang, Y.; Juan-Ling, F.U.; Zhou, Z.C. Inhibitory effect of thioredoxin on cytotoxicity of hydroquinone. Chin. J. Pharmacol. Toxicol. 2003, 17, 55-60.

32. Wu, P.H.; Nair, G.R.; Chu, I.M.; Wu, W.T. High cell density cultivation of Escherichia coli with surface anchored transglucosidase for use as whole-cell biocatalyst for alpha-arbutin synthesis. J. Ind. Microbiol. Biotechnol. 2008, 35, 95-101. [CrossRef] [PubMed]

33. Liu, Q.D.; Cheng, H.J.; Ma, X.Q.; Xu, N.; Liu, J.; Ma, Y.H. Expression, characterization and mutagenesis of a novel glutamate decarboxylase from Bacillus megaterium. Biotechnol. Lett. 2016, 38, 1107-1113. [CrossRef] [PubMed]

34. Liu, Q.; Ma, X.; Cheng, H.; Xu, N.; Liu, J.; Ma, Y. Co-expression of L-glutamate oxidase and catalase in Escherichia coli to produce alpha-ketoglutaric acid by whole-cell biocatalyst. Biotechnol. Lett. 2017, 39, 913-919. [CrossRef] [PubMed]

(C) 2018 by the authors. Licensee MDPI, Basel, Switzerland. This article is an open access article distributed under the terms and conditions of the Creative Commons Attribution (CC BY) license (http:/ / creativecommons.org/licenses/by/4.0/). 